\title{
Japan announces its "special distinguished grants" for 1989
}

\section{Tokyo}

BRAIN-RELATED research features prominently in this year's "special distinguished grants" announced at the end of last month by Japan's Ministry of Education, Science and Culture, taking three out of the ten awards. Big grants also go to research on solar flares and to development of new high-temperature superconductors to be made not from oxides but from organic compounds. The grants are the ministry's most lucrative and are intended for "internationally recognized research likely to produce outstanding results". Awards run for 3-5 years and are typically worth $\$ 1-2$ million.

As in previous years, molecular biology dominates the research projects selected. Professor Michio $\mathrm{Ui}$ in the Faculty of

\section{West Germany calls for ocean clean-up}

\section{Munich}

WEST German Environment Minister Klaus Töpfer (Christian Democrat) proposed a DM20,000 million plan last week for cleaning up the North Sea. Increased waste-disposal fees of between DM140 and DM300 annually per household would pay for the removal of nitrates and phosphates from sewage, costing DM14,000 million overall. Such pollution has been widely identified as a possible cause of the sudden death of more than 2,000 seals in the North Sea this summer.

In addition, industry would be called upon to contribute "several thousand million" Deutschmarks for various cleanup projects, said an Environment Ministry spokesman. The dumping of dilute sulphuric acid into the North Sea would be forbidden from 1989, and the burning of toxic waste on the high seas, starting in 1994.

Töpfer also called upon other countries to join in the anti- pollution crusade. The Scandinavian countries and the Netherlands have already declared their willingness to help. He specifically invited East Germany, Switzerland and Czechoslovakia to participate in the next North Sea conference in 1990 . Until now, these countries have refused to participate.

The opposition Social Democrats (SPD) claimed that Töpfer's programme is insufficient; they called it unfair to charge citizens more for sewage treatment while industry is handled "with kid gloves". The SPD proposed investing DM40,000 million to clean up the North Sea, with the lion's share to be paid by industry.

Steven Dickman
Pharmaceutical Sciences of Tokyo University receives $¥ 279$ million (\$2 million) over four years to study the molecular signalling systems that control cell growth and differentiation. And Professor Toru Yoshizawa of Kyoto University receives $¥ 190$ million over three years to investigate the molecular dynamics of colour and dark-light recognition in the eye.

The biggest grant of all, $¥ 316$ million for four years, goes to Professor Shosaku Numa of Kyoto University to continue his internationally recognized research on neurotransmitter receptors and ionic channels in muscles and the brain, Numa's second special distinguished grant.

With his new grant, Numa intends to elucidate the structure and function of the nicotinic acetylcholine receptor and sodium channels at the molecular level, to locate voltage sensors in the sodium channel, and look at the physiological characteristics of calcium channels and the muscarinic acetylcholine receptor.

Spiders will feature prominently in a three-year study of the brain by $\mathrm{Dr}$ Nobufumi Kawai of Tokyo Metropolitan Institute of Neurosciences, for which he receives $¥ 181$ million. The Japanese silk spider (Nephila clavata) injects insects trapped in its web with a poison that latches onto glutamine receptors in the insect's muscles, thereby paralysing the victim. In higher-level organisms, such as man, glutamine receptors are found in the brain and Kawai intends to locate the receptors using spiders' toxin labelled with isotopes. He also hopes to make glutamine receptor antibodies and use animal models of neural disorders to elucidate brain diseases.

Professor Hiroshi Wada in the medical faculty of Osaka University, on the other hand, will use more conventional techniques in his study of histamine receptors in the brain, for which he receives $¥ 174$ million over four years.

In the physical sciences, Dr Katsuo Tanaka of the National Astronomical Observatory will observe solar flares during the next solar maximum in 1991 with the X-ray satellite Solar A, which is due to be launched that year by the Institute of Space and Astronautical Science. And with his $¥ 216$ million grant his team will also develop a land-based telescope equipped with four sensors to observe sunspots, magnetic fields that connect pairs of sunspots, hydrogen alpha-radiation emitted from the periphery of flares created in the magnetic field, and gas flow on the solar surface.

As last year, a big grant goes to the development of new superconductors. But, interestingly, the award this year \section{Devil-may-care policies attacked} Paris

THE French Secretary of State for the Environment, Brice Lalonde, is under attack from both sides of the globe, accused of supporting a 'devil-may-care' attitude towards environmental pollution. For a former president of the French secion of the ecology action group, Friends of the Earth, this criticism is hard to swallow.

The controversy sprang up around a decision taken in Luxembourg on 28-29 June by environment ministers of the European Economic Community (EEC) to apply strict norms to limit pollution from car exhausts throughout the member states. Having accepted, reluctantly, the majority decision that catalytic converters should be fitted to small as well as larger cars, Lalonde changed his mind.

The problem, ostensibly, is that while the EEC has agreed minimum standards, some countries - notably West Germany and the Netherlands - have decided, unilaterally, to apply even stricter controls, in line with those already in force in the United States. This, said Lalonde in a

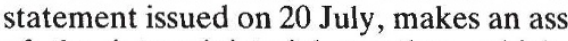
of the interministerial meeting, which, after all, sought to apply common norms.

But there may be a more subtle motive behind Lalonde's volte face. Even before the June meeting in Luxembourg, Jacques Calvet, the director of Peugot SA, one of France's two main car manufacturers, made it known that he disapproved of the proposal to require catalytic converters to be fitted to small cars. This, he said, would substantially increase production costs, reducing the international competitiveness of cars whose principal selling-point is their low cost. West Germany, he argued, would be less affected, as it mostly manufactures bigger cars, at the top end of the market, where the price increase would be less noticeable. Although France's other chief car manufacturer, Renault, has not voiced the same objections, it is thought that Calvet's remarks influenced the French government's decision.

Peter Coles

is to develop "high-temperature organic superconductors". The first organic superconductor was discovered in 1980 and since then about 30 superconducting organic compounds have been found, many of them by Japanese scientists. But the temperature at which they become superconducting is far below that of the new oxide superconductors. Nevertheless, Professor Isao Ikemoto of Tokyo Metropolitan University is determined to "challenge" the oxide superconductors with his $¥ 254$ million grant.

David Swinbanks 